\title{
TATACARA DAN RITUAL MENDIRIKAN RUMAH di KAMPUNG NAGA KEBUPATEN TASIKMALAYA
}

\author{
THE PROCEDURE AND RITUALS OF KAMPUNG NAGA \\ TASIKMALAYA REGENCY IN BUILD HOME \\ Nandang Rusnandar \\ Balai Pelestarian Nilai Budaya Bandung \\ Jalan Cinambo No. 136 Ujungberung-Bandung 42094 \\ e-mail: nd_roes@yahoo.co.id
}

\begin{abstract}
Abstrak
Kampung Naga di Kabupaten Tasikmalaya, merupakan kampung yang penduduknya masih berpegang teguh kepada adat istiadat dalam menjalankan kehidupan istiadat, melingkupi segala bentuk aspek kehidupan. Hal tersebut dapat terlihat dari tata cara mendirikan rumah. Keteguhan dalam mempertahankan adat ini menjadi kebiasaan tatacara mendirikan rumah dalam bentuk arsitektur yang ada di Kampung Adat Naga. Proses mendirikan rumah merupakan ritual yang tak putus mulai dari awal hingga akhir pembangunan. Proses mendirikan sebuah rumah merupakan kegiatan ritual yang secara masif dilakukan untuk mensucikan tempat tinggal (rumah) agar terbebas dari hal-hal yang bersifat gaib Bahkan dalam kenyataan kesehariannya, rumah memiliki fungsi sebagai tempat untuk ritual itu sendiri. Rumah yang dibangun bersama anggota keluarga sangat bermakna dalam. Segenap anggota masyarakat yang terlibat akan merasa memiliki bagian yang menjadi karyanya, sehingga keberadaan sebuah rumah adalah bagian utuh dari makrokosmosnya.Tujuan penelitian ini adalah untuk mendapatkan gambaran secara utuh dan mendalam tentang tata cara dan ritual yang mengungkap simbol dan nilai filosofisnya. Metode penelitian adalah metode kualitatif dengan teknik pengumpulan data berupa observasi langsung dan wawancara.
\end{abstract}

Katakunci: Tata cara, ritual, mendirikan, rumah.

\begin{abstract}
Kampung Naga in Tasikmalaya District, is a village whose people still cling to the customs and traditions in running life, encompasses all aspects of life forms. This can be seen from the procedure of building up their homes. The firmness in defending this custom becomes the habit of building up home procedures in the form of architecture of Kampung Naga. The process of building a house is a ritual that is unbroken from the beginning to the end of development. The process of setting up a home is a massive rituals performed to purify the residence (home) to be free from the things that are unseen.Even in the daily reality, the house has a function as a place for ritual itself. Houses are built by family members in has a deep meaning. All community members involved will give a feel as a part of their work, so that the existence of a home is an integral part of its macro-cosmos. The purpose of this study is to get a full and deep picture of the ordinances and rituals that reveal the symbols and philosophical values. The research method is a method of qualitativewith direct observation and interviews asthe data collection techniques.
\end{abstract}

Keywords: Procedure, rituals, build a home.

\section{A. PENDAHULUAN}

Dinamika pembangunan yang terus bergerak, tak mungkin ditahan untuk stagnan pada satu titik terminal yang statis.
Pembangunan akan terus memberi dampak yang positif maupun dampak negatif. Dampak pembangunan yang pada hakikatnya adalah pembaharuan di segala 
bidang dan merupakan pendorong utama terjadinya pergeseran, khususnya dalam bidang arsitektur. Pergeseran-pergeseran itu cepat atau lambat akan membawa perubahan terhadap bentuk, struktur dan fungsi arsitektur tradisional yang pada gilirannya akan menjurus kepada berubahnya atau bahkan punahnya arsitektur tradisional dalam masyarakat itu sendiri. Begitu pula pembangunan yang melanda hingga di pedesaan, khususnya di Kampung Naga, telah menyebabkan pergeseran terhadap wujud-wujud kebudayaan yang terkandung dalam bentuk arsitektur tradisionalnya.

Arsitektur sebagai sebuah karya pun tak lepas dari pengaruh dan dampak pembangunan yang menuntut perubahan.Sehingga banyak karya arsitektur yang tak bernilai kedaerahan atau keindonesiaan. Nilai-nilai di luar seni pun sangat berpengaruh terhadap perjalanan seni arsitektur di Jawa Barat maupun di Indonesia pada umumnya. Seiring dengan perkembangan zaman dan nilai-nilai seni arsitektur selalu dipengaruhi oleh seluruh aspek yang mewarnai kehidupan manusia, mulai dari politik, ekonomi, budaya, dan lain sebagainya. Karya seni arsitektur kini lebih menonjol nilai artifisial dibanding nilai fungsionalnya, sehingga karya seni arsitektur itu kadang-kadang bahkan malah sering tak bernada nilai kedaerahan.

Sebagai suatu bentuk aktivitas manusia yang saling berinteraksi dalam suatu sistem sosial, kebudayaan bersifat lebih konkret, dapat diamati dan diobservasi. Aktivitas manusia yang berinteraksi itu bisa ditata oleh gagasangagasan dari tema-tema berpikir yang ada dalam benaknya. Namun yang lebih penting dari semua itu adalah pemahaman nilai-nilai dan makna suatu kebudayaan yang telah dihasilkan dari cipta, karya, dan karsa manusia itu sendiri.

Mempelajari dan memahami kebudayaan dengan berbagai unsurnya mengandung konsekuensi untuk mendalami kedudukan makna-makna yang ada dalam kebudayaan itu sendiri. Kedudukan dan makna budaya suatu komunitas masyarakat berhubungan erat dengan sesuatu yang dipandang berharga atau bernilai bagi komunitas tertentu. Nilai budaya yang ada dalam suatu komunitas masyarakat diperlukan untuk mengatur bagaimana hubungan antara sesama anggota komunitas dalam suatu sistem sosial. Dalam mengatur hubungan antarmanusia, kebudayaan dinamakan pula dengan struktur normatif atau menurut istilah Ralp Linton, sebagai desigs for living (garis-garis atau petunjuk dalam hidup). Artinya, kebudayaan adalah suatu garis-garis pokok tentang perilaku atau bluepprint for behavior yang menetapkan peraturan-peraturan mengenai apa yang harus dilakukan, apa yang dilarang, dan lain sebagainya (Basrowi, 2005: 77).

Unsur-unsur normatif yang merupakan bagian dari kebudayaan adalah sebagai berikut: (1) unsur-unsur yang menyangkut penilaian (valuational elements), misalnya apa yang baik dan buruk, apa yang menyenangkan dan tidak menyenangkan, apa yang sesuai dengan keinginan, dan apa yang tidak sesuai dengan keinginan; (2) unsur-unsur yang berhubungan dengan apa yang seharusnya (precriptive elements), seperti bagaimana orang harus berlaku; (3) unsur-unsur yang menyangkut kepercayaan (cognitive elements), seperti harus mengadakan upacara adat pada saat kelahiran, pertunangan, perkawinan, pertanian, dan lain-lain.

Keaneka-ragaman budaya yang ada pada masyarakat Indonesia sangat banyak dan menarik untuk diamati dan diteliti, karena didalamnya terkandung makna dan nilai-nilai berharga yang disampaikan secara khas dan unik lewat simbol-simbol yang diciptakan oleh manusia itu sendiri. Salah satu bentuk dari kebudayaan tersebut adalah kegiatan upacara adat.Pelaksanaan upacara dipilih waktu yang terbaik yaitu hari dan tanggal pelaksanaannya yang membawa keberuntungan. 
Penelitian-penelitian mengenai upacara telah banyak dilakukan oleh para antropolog. Berbagai etnografi klasik banyak meng-gambarkan proses-proses upacara baik upacara peralihan ataupun upacara pe-ngukuhan. Upacara-upacara ini merupakan bagian yang selalu ada dalam masyarakat-mayarakat tradisional, terutama di Indonesia. Adapun penelitianpenelitian mengenai upacara ini dilakukan dari mulai Radclife-Brown (1922), Turner (1967), Geertz (1960), Hertz (1907).

Upacara adalah suatu tindakan atau serangkaian tindakan yang dilaksanakan menurut adat istiadat atau keagamaan yang menandai kesucian dan kekhidmatan suatu perbuatan (Shadily, 1984:31). Studi antropologis tentang upacara dilakukan oleh Radcliffe Brown tahun 1922 (Keesing, 1992:109). Upacara dianggap dapat mempertebal perasaan kolektif dan integrasi sosial. Turner (Keesing, 1992) berargumen bahwa dalam upacara, simbolsimbol muncul dan terlihat sedemikian menggambarkan suatu struktur masyarakat. Kepentingan pribadi secara sistematis berhubungan dengan kepentingan umum; drama yang dimainkan secara kolektif memiliki arti pribadi dan arti bawah sadar.

Upacara, mitos, dan penjabaranpenjabaran simbolis dilihat sebagai cermin dan dukungan dari organisasi masyarakat (Keesing, 1992: 113). Dalam arti, bahwa upacara merupakan integrasi masyarakat. Bagaimanapun, upacara menurut Barth (1975:210) dan (Keesing 1992:130) menjadikan seluruh penduduk sebuah kelompok yang bersatu dan sebuah tujuan umum.

Pada masyarakat-masyarakat tradisional, religi berkaitan erat dengan struktur sosialmasyarakat. Geertz (1981) menyatakan melalui pendekatan religi, segenap aspek kehidupan masyarakat dapat dilihat sebagai sebuah sistem, dimana religi sebagai landasannya. Geertz (1981), mengklasifikasikan sistem sosial masyarakat Jawa di Mojokuto berdasarkan religi, yaitu terdapatnya abangan, santri, dan priyayi. Agama menurut Geertz (1981) memainkan peranan yang integratif dan menciptakan harmoni sosial dalam masyarakat. Geertz (1966:4) dan Keesing (1992:94) menyatakan sebuah definisi agama:

Agama adalah sistem simbol yang berfungsi untuk menanamkan semangat dan motivasi yang kuat, mendalam, dan bertahan lama pada manusia dengan menciptakan konsepsi yang bersifat umum tentang eksistensi, dan membungkus konsepsi-konsepsi itu sedemikian rupa dalam suasana faktualitas sehingga suasana dan motivasi itu kelihatan sangat realistis.

Dengan kata lain, agama menentukan keadaan dunia sedemikian rupa sehingga menimbulkan sikap yang tepat. Baik sifat dunia maupun emosi serta motif manusia saling menegakkan dan memperkuat. Agama dapat memberi pengesahan dalam arti dapat menerima kekuatan-kekuatan di alam semesta yang mengendalikan dan menopang tata susila dan tata sosial masyarakat. Dengan demikian, agama menambah kemampuan manusia untuk menghadapi kelemahan kehidupannya (Keesing, 1992).

Keesing (1992) mengutarakan salah satu cara untuk menginterpretasikan hubungan antara agama dan kehidupan sosial manusia adalah dengan menganggap agama sebagai proyeksi dari alam manusia. Dalam alam manusia, segala aspek kehidupan sosial yang menuntut adanya hubungan antarmanusia telihat bahwa agama mengatur berbagai pola-pola kelakuan untuk menciptakan harmoni dan integrasi dalam kehidupan masyarakat.

Kaitan antara keagamaan dan upacara dapat terlihat dalam Koentjaraningrat (1981), yang disebut dengan religious behavior (kelakuan keagamaan). Agama berfungsi sebagai pengendalian sosial yang dapat pula terkait atau menjadi landasan bagi adat istiadat. Mengacu pada Koentjaraningrat (1981), kelakuan keagamaan yang dilaksanakan menurut tata kelakuan yang baku atau religious ceremonies setidaknya memiliki 
empat komponen, yaitu (1) tempat upacara,(2) saat upacara,(3) benda-benda dan alat-alat upacara (4) orang-orang yang melakukan dan memimpin upacara.

Dalam upacara membangun rumah, terdapat beberapa unsur yang berkaitan dengan sistem kepercayaan, yaitu, berdoa dan berprosesi. Unsur-unsur ini diuraikan dalam Koentjaraningrat (1981).

Masyarakat adat Kampung Naga, merupakan masyarakat yang masih teguh memegang erat tradisi nenek moyangnya, walaupun mereka berlatarbelakang agama Islam. Perpaduan antara agama dan budaya (tradisi) menjadi sesuatu upaya mengharmoniskan hidup dalam mencari makna keselarasan dengan alam.

\section{B. METODE PENELITIAN}

Penelitian mengenai tatacara dan upacara membangun rumah di Kampung Naga Kabupaten Tasikmalaya ini merupakan penelitian yang bersifat kualitatif. Pendekatan seperti ini digunakan untuk memahami persoalan sosial dan budaya manusia berdasarkan pada suatu pengembangan gambaran yang kompleks dan holistik, dibangun dengan susunan kata-kata, menyajikan pandangan detil dari informan dan dilaksanakan di lingkungan alamiahnya (Hidayah, 2006).

Adapun teknik pengumpulan data dilakukan dengan tiga cara, yaitu: (1) observasi partisipasi (participant observation), (2) wawancara mendalam (in-depth interview), dan (3) penggunaan dokumen (dokument used). Teknik observasi partisipasi. Partisipan bertindak sebagai pengamat aktif dengan menyaksikan dan mengikuti kegiatan yang dilakukan, mencatat dan melakukan tanya jawab dengan informan, kemudian dilanjutkan dengan analisis secara cermat tentang apa yang telah diamati tersebut. Wawancara terbuka atau mendalam, yang memberi keleluasaan bagi informan untuk memberi pandangan-pandangan secara bebas (Koentjaraningrat, 1989:30). Wawancara demikian ini memungkinkan si peneliti untuk mengajukan pertanyaan- pertanyaan secara mendalam. Karena itu, untuk melengkapi data penelitian ini, khususnya dalam upaya memperoleh data yang akurat tentang penelitian ini, peneliti melakukan wawancara dengan informan. Wawancara jenis ini dilakukan karena bersifat luwes, susunan pertanyaan atau kata-kata dapat diubah saat wawancara dilaksanakan, disesuaikan dengan kebutuhan, dan kondisi informan yang dihadapi.

\section{HASIL DAN BAHASAN \\ 1. Kondisi Lingkungan}

Kampung Naga adalah nama sebuah komplek pemukiman masyarakat adat di daerah Tasikmalaya. Kampung ini terletak di cekungan tanah yang dikelilingi oleh perbukitan hijau, seolah kampung ini bersembunyi di balik rindangnya pepohonan. Kampung Naga seolah tak tersentuh oleh peradaban modern, namun bila dilihat dari perjalanan sejarahnya dari tahun 1921 yang merupakan awal kampung hingga kini tahun 2007 sudah banyak perubahan yang dilakukan oleh masyarakatnya. Dalam administrasi Pemerintahan, Kampung Naga termasuk dalam wilayah Kabupaten Tasikmalaya, tepatnya berada di Kecamatan Salawu, Desa Neglasari. Jarak kampung ini dengan Kecamatan Salawu sekitar $5 \mathrm{~km}$ dan dengan Desa Neglasari 800 m. Lokasinya berada di tepi jalan raya yang menghubungkan daerah Garut dengan Tasikmalaya. Kota Tasikmalaya posisinya sekitar $30 \mathrm{~km}$ ke arah timur dan kota Garut sekitar $26 \mathrm{~km}$ ke arah barat. Jarak wilayah ini dengan ibu kota Provinsi Jawa Barat (Bandung) sekitar $106 \mathrm{~km}$. Transportasi pulang pergi dari Bandung ke Kampung Naga dapat ditempuh dengan menggunakan kendaraan umum bus mini jurusan Bandung - Garut - Singaparna. Bila menggunakan bus, waktu tempuh dari Bandung ke Kampung Naga memakan waktu sekitar 3 jam.

Batas-batas wilayah Kampung Naga meliputi: sebelah utara berbatasan dengan Desa Cigalontang; sebelah selatan dibatasi 
oleh bukit dan jalan raya Garut Tasikmalaya; sebelah barat dibatasi oleh Bukit Naga yang sekaligus sebagai batas pemisah antara Kampung Naga dengan Kampung Babakan; dan di sebelah timur dibatasi oleh Sungai Ciwulan (Maria dkk.1995:10).

Memasuki kawasan Kampung Naga, kita harus melewati satu-satunya jalan yang berupa anak tangga; setiap orang yang menghitung jumlah anak tangga ini tidak selalu sama, Her Suganda ${ }^{1}$ menyatakan bahwa Kampung Naga merupakan Kampung di bawah 335 anak tangga, dan ada yang menyatakan anak tangga itu berjumlah 350 anak tangga. Kondisi anak tangga berkelok-kelok dan curam. Saat menuju perkampungan kita harus berjalan menurun, sebaliknya ketika pulang atau menuju jalan raya kita harus berjalan menanjak. Anak tangga yang dilalui saat ini kondisinya sudah cukup baik dan disemen, sehingga walaupun turun hujan, jalanan tidak menjadi licin. Sehabis anak tangga terakhir, kita menapaki jalan tanah yang lebarnya cukup untuk tiga orang berjalan bersisian. Jalan ini merupakan tanggul Sungai Ciwulan yang membatasi antara kawasan Kampung Naga dengan kawasan Bukit Biul sebagai bukit atau leuweung tutupan. Kampung Naga merupakan sebuah cekungan yang berada di lembah yang berketinggian ratarata $500 \mathrm{~m}$ di atas permukaan laut, bila dilihat dari atas bukit, maka Kampung Naga ini menyerupai mangkuk besar yang terpotong.

Di sisi kiri dan kanan jalan tampak pemandangan yang berbeda. Sebelah kiri tampak persawahan, ladang dan kolam, serta beberapa mata air yang keluar dari sela-sela dinding tebing. Sedangkan di sebelah kanan terdapat Sungai Ciwulan yang tidak begitu dalam. Di seberang sungai tampak hutan Biuk, hutan yang dikeramatkan oleh penduduk setempat. Pepohonannya hijau dan lebat,

${ }^{1}$ Her Suganda. 2006. Kampung Naga Mempertahankan Tradisi. Bandung. Kiblat. hal. 15. dedaunannya hampir menyentuh air sungai. Semakin mendekati perkampungan, di sebelah kiri jalan terdapat kandang-kandang hewan piaraan penduduk, yaitu kambing. Selanjutnya, lebih ke belakang terdapat lesung dan jamban-jamban pancuran di tepi-tepi kolam. Suara air mengalir dari pancuran lebih jelas menandakan perkampungan tinggal beberapa langkah lagi. Perjalanan yang ditempuh dari jalan raya hingga perkampungan ini menempuh waktu sekitar 30 menit.

Kampung Naga yang dilewati Sungai Ciwulan dan dua bukit subur ini, berada pada ketinggian $500 \mathrm{~m}$ dari permukaan laut. Sehingga bila kita memasuki area Kampung Naga setelah perjalanan yang sangat melelahkan dengan menuruni sejumlah anak tangga, maka begitu memasuki kampung ini akan terasa nyaman, karena suhu udara di kampung ini berkisar antara $21,5^{0}$ sampai dengan $23^{0}$ Celcius. Kelembaban udaranya berkisar sekitar $75 \%$ sampai $85 \%$ dan curah hujan per tahun rata-rata $289 \mathrm{~mm}$. Oleh karena itu, suhu di Kampung Naga dapat dikatakan sangat sejuk, baik pada siang maupun malam hari, dan sangat dingin pada waktu menjelang pagi.

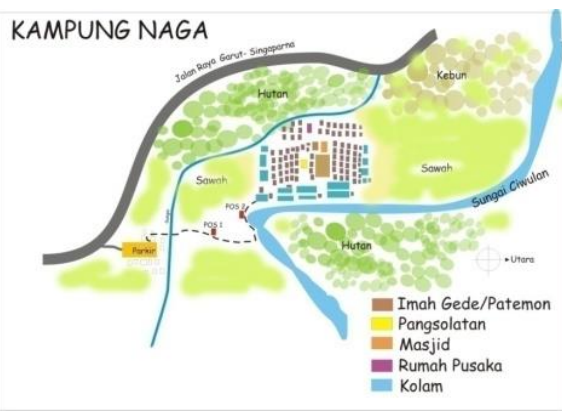

Gambar 1. Peta Kampung Naga Sumber: Nandang Rusnandar

Posisi dan letak Kampung Naga yang berada di sebuah lembah merupakan sebuah perkampungan yang menyerupai sebelah mangkuk yang terpecah, hal itu dapat kita lihat bila kita menuruni jalan setapak atau anak tangga yang terbuat dari adukan semen. Ciri khas Kampung Naga 
akan segera tampak dari kejauhan, merupakan gundukan perkampungan dengan ciri fisik yang khas, rumah beratap ijuk, bila dilihat dari kejauhan merupakan jajaran atap hitam di tengah hijaunya rimbun pepohonan. Ciri khas lainnya secara fisik adalah dinding rumah yang berwarna putih karena bilik yang terbuat dari bambu itu berlabur kapur putih dengan jendela terlihat titik noktah hitam yang menempel pada bilik tersebut.

Secara topografi, letak Kampung Naga berada di kaki sebuah lembah, di mana permukaan tanah di sebelah baratlebih tinggi daripada permukaan tanah di sebelah timur. Kondisi seperti ini bagi masyarakat Kampung Naga merupakan tanah yang baik sesuai dengan apa yang dipercayai dalam sistem kepercayaannya, tanah seperti ini disebut sebagai 'taneuh bahe ngetan' artinya baik untuk permukiman dan pertanian. Kondisi ini secara rasional pun dapat dipercaya bahwa dengan kemiringan ke arah timur 'bahe ngetan' menunjukkan bahwa sinar matahari 'ultra violet' akan lebih banyak diterima dan penghuni kampung ini akan lebih sehat karena pengaruh sinar ultra violet tadi di waktu pagi hari.

Keunikan Kampung Naga, di samping sebagai kampung adat karena memiliki ciri-ciri fisik tertentu, seperti bentuk rumah yang sama, memiliki adat istiadat yang dipelihara dengan baik dan diturunkan dari generasi ke generasi, memiliki sistem pertabuan yang kuat dalam memelihara kelangsungan hidupnya, dan sebagainya. Dari segi arsitektural, rumah-rumah di Kampung Naga menunjukkan proses adaptasi manusia yang disesuaikan dengan alam lingkungannya, sehingga tata letak dan bentuk rumah sangat artistik disesuaikan dengan kontur tanah yang ada.

Rumah tradisional Kampung Naga, mencirikan bahwa rumah yang ada di kampung itu adalah rumah yang berarsitektur tradisional, baik dilihat dari bentuk atap, pembagian ruangan dalam rumah, jenis bahan-bahan pembuatan dan tata cara untuk membangun rumah tersebut.

Secara keseluruhan rumah-rumah yang ada di Kampung Naga hampir seluruhnya berhadap-hadapan. Secara fisik dapat dilihat dari setiap pintu masuk; (pintu masuk ke tepas maupun ke dapur hanya berada di depan rumah, tidak ada yang berada di belakang ataupun di samping rumah) rumah selalu berhadapan dengan pintu masuk rumah yang ada di hadapannya.

Jenis dan bentuk rumah di Kampung Naga adalah panggung, secara umum menunjukkan bahwa rumah yang ada di Kampung Naga dengan rumah yang ada di Jawa Barat pada umumnya sama berupa rumah panggung. Namun rumah di Kampung Naga memiliki daya pikat dan ciri khas tersendiri dibanding dengan rumah-rumah pada umumnya.

Secara administratif pemerintahan, Kampung Naga termasuk dalam wilayah Rukun Tetangga (RT), Rukun Warga (RW) 01. Wilayah RW 01 sendiri meliputi Kampung Babakan, Kampung Pawitan, Kampung Pondok Waru, Kampung Bantar Sari, Kampung Markica, Kampung Legok Dage, Kampung Kuang dan Kampung Neundeut. Hal itu bila dikaitkan dengan kondisi budaya disebut sebagai Warga Sanaga, yaitu masyarakat Naga yang bermukim di luar Kampung Naga sendiri. Pola pemukiman di Kampung Naga tampak rapih. Hal itu terlihat sejak pengunjung barada di anak tangga terakhir. Sejauh mata memandang, tampak sekumpulan atap berwarna hitam menutupi rumah-rumah warga Naga yang berbaris rapi. Pemandangan tersebut sangat kontras dengan keadaan sekelilingnya, yaitu hutan lebat yang serba hijau. Di areal pemukiman yang seluas 1,5 ha, rumahrumah penduduk tertata rapih, dengan pola memanjang dari timur ke barat atau dari barat ke timur. Barisan rumah menghadap kearah utara atau selatan. Secara fisik, rumah-rumah tersebut seragam. Bangunannya berbentuk rumah panggung, dinding dan pintu terbuat dari anyaman 
bambu, jendela ruang tamu berkaca dan jendela dapur berkisi-kisi kayu. Semua bilik rumah berlabur kapur putih atau berbilik dengan warna aslinya tanpa laburan kapur putih, masing-masing pekarangan yang luasnya terbatas tampak bersih dari sampah. Pada saat penelitian ini dilakukan, jumlah bangunan yang ada di Kampung Naga sebanyak 111 bangunan. 108 bangunan di antaranya merupakan bangunan tempat tingal (rumah), tiga bangunan lainnya terdiri atas : Masjid, Bumi Ageung dan Bale Patemon yang bentuk dan ukurannya lebih besar dari rumah. Di belakang rumah terdapat pula bangunan lain yaitu leuit (lumbung padi) berjajar mendekati kaki bukit dan kandang jaga. Sedangkan di atas kolam ada pula bangunan khas Kampung Naga, yaitu bangunan saung lisung, kandang (kandang domba) dan Pancilingan (jamban).

Tanah di Kampung Naga merupakan tanah ulayat, yaitu tanah milik adat, sehingga bagi siapa pun warga Kampung Naga yang akan membangun rumah, tidak perlu membeli tanah, cukup meminta izin kepada Kuncen atau Ketua Adat. Dahulu, tepatnya sekitar tahun 1921 bangunan rumah di Kampung Naga tidak sebanyak seperti sekarang, yaitu hanya 7 buah. Masing-masing rumah belum berjendela seperti sekarang. Pada tahun 1950 terjadi peristiwa pembakaran kampung oleh kelompok DI / TII yang menghanguskan hampir seluruh bangunan yang ada serta benda-benda pusaka yang disimpan di Bumi Ageung. Warga kampung yang telah kehilangan rumah, kembali membangun rumah pada lokasi yang sama. Rumahrumah yang didirikan untuk tempat tinggal tersebut mengalami perubahan. Bangunan rumah penduduk tampak seragam berbentuk rumah panggung, dan dibuat dari bahan yang sama. Atap rumah terbuat dari ijuk dengan bentuk yang khas yang disebut julang ngapak artinya sayap burung yang sedang mengembang. Selain rumah-rumah sekarang berjendela, bahan rumah semua terbuat dari kayu dan anyaman bambu. Bangunan rumah yang berjendela ini memungkinkan pemiliknya dapat saling menjaga keamanan karena dapat mengawasi keadaan di luar rumah lewat jendela masing-masing.

Selain tidak ada penerangan listrik pada malam hari, perabotan rumah yang dimiliki penduduk sangat sedikit, hanya lemari. Mereka tidak memiliki seperangkat kursi untuk menerima tamu, makan dan tidur cukup dengan menggelar tikar di lantai palupuh. Namun dengan masuknya pengaruh dari luar, sekarang perabotan rumah sebagian penduduk bertambah ragamnya dengan adanya ranjang kayu, radio, tape dan televisi yang menggunakan tenaga accu. Rumah-rumah yang dilengkapi televisi tampak pada atapnya yang dipancangi antena dengan tongkat yang tinggi-tinggi.

Arsitektur adalah wujud kebudayaan terbesar, karena di dalamnya terkandung sekaligus wujud ideal, wujud sosial, dan wujud material yang terpadu dalam bentukan yang berdimensi. Arsitektur terjelma dalam batasan-batasan ruang dan waktu, di dalamnya terkandung pandangan hidup, sikap religius, dan tatanan sosial masyarakatnya. Selain itu juga, dibangun melalui ilmu dan teknologi yang ada serta menggunakan bahan-bahan yang disediakan alam sekitarnya. Dalam fungsinya, arsitektur langsung bersinggungan dengan kegiatan manusia dan masyarakatnya, baik jasmaniah maupun rohaniah secara sadar ataupun tidak sadar. Hubungan-hubungan ini terjadi tidak hanya dalam kurun hidup seorang manusia, namun justru sepanjang hidup masyarakat dan kebudayaannya sendiri.

Sebagai unsur kebudayaan, arsitektur selalu merupakan sekelompok pola dan bentukan baku yang merupakan pantulan sikap budayanya. Seperti telah disebutkan di atas, pola dan bentukan ini sama sekali tidak statis namun selalu berubah, menyesuaikan diri dengan perjalanan sejarah dan pengalaman budaya; baik individu maupun kelompoknya. Keterikatan pada pola jauh lebih erat daripada keterikatan pada bentukan, bahan, 
dan teknologi. Wujud ideal yang tertanam pada dunia bawah sadar ini membutuhkan waktu jauh lebih lama untuk berubah dan justru sisi ini yang sering dilupakan.

Nenek moyang (karuhun) Sunda telah memiliki kearifan dalam penataan lingkungan (ekologi). Salah satu contoh yaitu masyarakat Kampung Naga, salah satu bentuk dalam menjaga kelestarian alamnya itu dengan tabu. Kelestarian alam sekitar dapat dijaga dengan adanya tabu yang sangat mengikat sikap hidup masyarakatnya. Perjalanan sejarah Kampung Naga mulai dari awal hingga sekarang adalah gambaran adanya kesadaran akan lingkungan alam sekitar. Perpaduan antara kearifan tradisional yang diturunkan melalui karuhunnya dengan tantangan alam yang ada, mampu menciptakan hidup yang harmonis.

Sikap tabu untuk melakukan dan berbuat sesuatu (khususnya dalam pembuatan rumah) sangat dihormati masyarakatnya, walaupun kini dalam suatu siatuasi yang menuntut untuk berubah sesuai dengan gelombang zaman. Rasionalisasi yang diberikan oleh pimpinan masyarakat adalah jawaban tentang kearifan dalam menjaga kelestarian alam sekitarnya.

Ada dua sisi yang tak dapat ditolak oleh masyarakat Kampung Naga, yaitu (1) sisi perubahan zaman yang menuntut manusia untuk berubah. Hal itu disebabkan adanya mobilitas antara penduduknya dengan dunia luar. (2) adanya sisi yang lebih prinsip dalam hidupnya, yaitu sikap religius yang harus dipertahankan sebagai pedoman hidupnya. Kedua sisi yang saling berseberangan ini mereka ikuti dengan jalan mencoba merasionalkan tabu dengan nilai-nilai baru sesuai dengan perubahan zaman.

Sikap pertentangan dua sisi yang berseberangan itu akan sangat terlihat pula pada kehidupan masyarakat orang Rawayan (Baduy) adalah salah satu sisasisa karuhun Sunda zaman dahulu yang dikenal kuat memegang prinsip adat. Mereka memiliki kearifan ekologis yang tercermin dari pegangan hidup mereka, yaitu seperti ungkapan berikut:

- Ngaraksa Sasaka Pusaka Buana mengandung makna, menjaga warisan suci di atas bumi. Adapun yang dimaksud dengan "warisan suci di atas bumi" adalah kelestarian alam yang masih terjaga. Tanah yang masih tetap subur, sumber air yang belum tercemar, udara yang bersih, sehat, nyaman belum terkena polusi, serta bumi yang masih terjaga keseimbangan ekologisnya. Sasaka Pusaka Buana adalah buana bumi yang masih tetap layak, sehat, nyaman untuk dihuni oleh manusia dan makhluk lainnya, yang kelak akan diwariskan kepada anak cucu kita.

- Lojor teu beunang dipotong, pondok teu beunang disambung, artinya: Panjang tak boleh dipotong, pendek tak boleh disambung. Ini adalah esensi hidup dari konsep konservasi yang menyatakan menjaga dan melestarikan kelangsungan proses perubahan alamiah secara wajar.

- Ngasuh ratu ngajayak menak, ngabaratakeun nusa teulung puluh telu, bagawan sawidak lima, panca salawe nagara.Maksudnya, sebagai warga negara yang bertanggung jawab, paling tidak secara moril harus loyal kepada pemerintah dan pimpinan negara, dengan berbagai upaya dan cara. Begitu pula para pemimpin bangsa dan masyarakat. Dalam upaya menjaga kewajibannya dan menghindarkan diri dari tindak nista tercela, perlu ikut mendukung dengan keteladanan. Secara spiritual, dengan berdoa dan bertapa, agar negara dan bangsa senantiasa selamat sejahtera, aman damai abadi. Terhindar dari segala macam bencana dan malapetaka.

- Mipit kudu amit, ngala kudu menta (memetik harus permisi, mengambil mesti meminta). Jika prinsip ini dipadukan dengan prinsip "lojor teu beunang dipotong, pondok teu beunang disambung", maka prinsip orang Rawayan untuk menjaga 
kelestarian alam merupakan prinsip yang lengkap, utuh, dan serasi.

Dengan mematuhi prinsip itu orang Rawayan menerima alam menurut kondisi kodrati. Mereka tabu untuk mengubah wajah atau permukaan bumi. Oleh karena itu, dalam menentukan lokasi rumah, kampung, desa, atau lahan pemukimannya, mereka memiliki salah satu alternatif dari beberapa macam lahan yang bersifat baik dan layak huni.

Begitu pula dengan masyarakat Kampung Naga, mereka menyadari bahwa dengan mematuhi larangan atau tabu yang menjadi patokan hidupnya adalah suatu cara dan jalan untuk menyikapi hidup. Proses rasionalisasi tabu yang dilakukan oleh para pemimpin masyarakatnya adalah sikap arif yang paling baik untuk menyikapi dinamika penduduknya dalam menghadapi perubahan dan tantangan alam. Rasionalisasi ini tidak mengubah pola pikir tradisional menjadi modern, namun proses rasionalisasi ini merupakan pola pikir yang mendukung adanya perubahan tanpa mengubah asas sikap hidupnya.

Dalam kehidupan kesehariannya, masyarakat Kampung Naga tak lepas dari siklus alam yang mengitarinya, segala sesuatu selalu berhubungan erat tidak terputus. Apabila kita lihat bahwa waktu atau perputaran bumi, bulan, dan matahari tak lepas dari pengamatan yang dijadikan acuan dan patokan dalam langkah kesehariannya. Patokan itu merupakan satu tatanan permanen yang apabila dilepaskan atau diabaikan akan terjadi kerusakan alam dan manusianya, itu adalah konsekuensinya. Kearifan manusia dalam mengakomodir gejala alam ini adalah suatu pranata yang sudah menjadi konsep hidupnya dalam keseharian. Konsep itu andalan dan pegangan dalam segala aspek kehidupan yang dipergunakan baik oleh petani, pembuat rumah, konseptor, pedagang, dan lain-lain. Ada semacam perhitungan-perhitungan hari baik dan hari-hari pantangan untuk melaksanakan suatu pekerjaan sesuai dengan perputaran bumi, bulan, dan matahari bagi seseorang. Perhitungan itu disebut sebagai palintangan.

Di negara-negara Barat (negaranegara industri) waktu diistilahkan denganjam yang dapat diukur, menurut Benjamin Franklin, "waktu juga dapat disamakan dengan uang", bukan sebagai sesuatu yang sesuai dengan kenyataan hidup manusia. Karena itu, bagi mereka kesamaan waktu dan kehidupan manusia merupakan pengelolaan teknologis. Bagi manusia Sunda (khususnya masyarakat Kampung Naga), waktu dipergunakan untuk memenuhi kebutuhan hidup yang sampai sekarang merupakan pusat pemikiran dan tindakan. Keselarasan hidup sesama manusia, manusia dengan alam, manusia dengan Tuhan, manusia dengan waktu masih merupakan pegangan hidupnya. Bagi manusia masyarakat Kampung Naga, waktu dan ruang merupakan hukum perulangan yang berhubungan dengan prinsip kosmis, si petani menyelaraskan diri dengan musimnya dan dengan pergantian siang dan malam.

Kepercayaan terhadap ramalan hari baik dan buruk, keberuntungan serta ramalan-ramalan lainnya merupakan salah satu bagian dari sistem pengetahuan yang dimilikinya dan sangat erat dengan sistem religi yang dianutnya. Masyarakat Kampung Naga pada dasarnya masih percaya bahwa kehidupan ini selalu berada dalam pengaruh alam gaib, benda-benda serta bintang-bintang lainnya yang saling memengaruhi.

Mengenai kebenaran dari hasil palintangan ini, menyangkut sejauhmana keyakinan seseorang atau sekelompok orang dalam penerapannya, sehingga apa yang diharapkan dari niat atau pekerjaan itu tidak terlalu jauh meleset atau bahkan tidak berdampak negatif. Pada umumnya masyarakat Kampung Naga pun dengan latar belakang agama Islam sangat intens dengan kepercayaan mengenai perhitungan ini. Pada dasarnya kepercayaan mengenai per-hitunganini adalah untuk menjaga 
hubungan yang harmonis antara manusia dengan alamnya atau dengan alam gaib. Agar hubungan yang harmonis ini terus tercipta, maka diadakanlah upacaraupacara ritual, seperti dalam tata cara membangun rumah; mulai dari tahapan awal hingga rumah selesai dibangun, selalu diwarnai dengan upacara ritual.

\section{Tatacara Mendirikan Bangunan}

Alam, seakan penuh berkah dengan isyarat yang jika perlu tahu kuncinya, kita dapat membukakan pesannya untuk kemudian menerjemahkan dan menindaklanjutinya. Hanya mereka yang masih kental bersinggungan dengan alam memiliki kepekaan itu. Manusia yang semakin jauh dari alam, seperti penduduk kota misalnya, semakin kurang peka untuk membaca isyarat yang dikirimkan alam itu. Corbu, (dalam Tjahjono, 2010:13) menarik satu kesimpulan bahwa tindakan hakiki membangun orang primitif yang terpenting adalah tataolah membangun, meski dalam berpindah, adalah mendudukkan tempat suci bagi Yang Maha Kuasa terlebih dahulu di tempat yang layak. Tindakan tersebut segera dilakukan setelah batas tempat berpijak ditentukan, sering melalui pengetahuan geometri. Setelah itu manusia boleh menghuni. Hatinya telah tenteram.

Mendirikan bangunan atau rumah bagi warga masyarakat Kampung Naga, adalah sebuah proses ritus yang harus dipenuhi persyaratannya. Mulai dari awal persiapan untuk mempersiapkan bahanbahan hingga penempatan rumah itu sendiri adalah sebuah ritus yang dilaksanakan penuh dengan kehati-hatian bagi pemiliknya, sehingga menimbulkan keyakinan diri dalam ketenangan untuk mendiaminya. Dan biasanya untuk mendirikan bangunan sebuah rumah merupakan tanggungjawab bersama oleh seluruh warga Kampung Naga, sehingga pembangunannya dilakukan secara gotong royong. Untuk pembangunan sebuah rumah biasanya diawali dengan tahap persiapan atau Babahanan (mengumpulkan bahan), tahap
Ngadegkeun(mendirikan rumah), tahap Ngeusian(menempati).

\section{Tahap Persiapan}

Tahap persiapan adalah proses yang atau merupakan bagian yang paling memakan waktu dalam pembangunan sebuah rumah. Ada beberapa tahap dalam tata cara mendirikan sebuah rumah yang dilakukan oleh warga Kampung Naga. Hal tersebut dilakukan sesuai dengan ketentuan dan adat istiadat yang berlaku dan bila salah satu tahap tidak laksanakan maka akan memberikan akibat yang tidak diinginkan.

Bagi masyarakat Kampung Naga, dalam memenuhi kebutuhan akan bahan bangunan selalu mengandalkan bahanbahan dari alam sekitar mereka. Kayu, bambu, daun eurih (alang-alang) atau daun tepus, dan ijuk diambil dari kebun sekitar. Bahan-bahan tersebut ada yang dibeli dari warga lain atau diambil dari kebunnya sendiri. Daun tepus atau daun eurih diambil dari kebun di daerah Nangtang yang jarak dari Kampung Naga kira-kira tiga jam perjalanan bolak-balik, sulit untuk mengukur jarak karena mereka harus melewati hutan. Batu tatapakan yang berbentuk lempar (bulat rata) dapat diambil dari Sungai Ciwulan, namun batu tatapakan papras atau batu jangkung dibeli dari daerah lain. Bahan-bahan yang telah siap untuk rangka rumah, kemudian diolah dan hari pembangunan ditentukan.

Untuk pembangunan sebuah rumah diperlukan beberapa tahapan, maka tahapan-tahapan pembuatan rumah dilaksanakan dengan adat yang telah berlaku. Sehari sebelum pembangunan rumah dimulai, diadakan musyawarah kampung untuk membicarakan pembangunan rumah. Upacara salametan akan memulai seluruh rangkaian acara ngadegkeun (mendirikan rumah) atau seperti :
a. Babahanan (mengumpulkan bahan), dan Ngamprah(meminta ijin)
Bagi warga Kampung Naga yang ingin membuat rumah atau disebut lulugu, 
biasanya tidak sekaligus melakukan pembangunan rumahnya, lulugu melakukan apa yang disebut babahanan. Babahanan merupakan asal kata dari bahan yang artinya bahan material yang akan dijadikan barang jadi. Kata ulang babahanan menunjukkan arti mengumpulkan semua material yang diperlukan. Babahanan tidak saja berarti hanya mengumpulkan, di dalamnya terkandung maksud juga mempersiapkan secara spiritual sebelum pembangunan rumah. Lamanya waktu babahanan tergantung pada kesiapan si pemilik rumah dalam mengumpulkan material bahan rumah. Biasanya babahanan dilakukan secara menyicil sedikit-sedikit, mulai dari mengumpulkan bahan-bahan kecil seperti paku, awi (bambu) untuk membuat ereng yang harus dikeueum (direndam) di dalam kolam yang memakan waktu lama, atau memotong kayu di hutan dan menggergajinya menjadi bagian-bagian tertentu untuk tiang, mengumpulkan daun nipah atau eurih dan material lainnya. Bahan yang dirasa paling mahal untuk membuat sebuah rumah adalah membeli ijuk untuk atap.

Keperluan babahanan ini pun dilakukan sesuai dengan kebutuhan dalam membangun rumah, sehingga si pemilik rumah dapat dengan menyicil dan memperkirakan berapa biaya yang akan diperlukan. Misalnya untuk rumah berukuran $5 \times 7 \mathrm{~m}$, ia akan memerlukan jumlah kayu sekitar $5 \mathrm{~m}^{3}$ dan ijuk sekitar 2.000 kakab (lembar), sedangkan untuk rumah berukuran $7 \times 9 \mathrm{~m}$ ia akan memerlukan kayu $11 \mathrm{~m}^{3}$ dan ijuk sekitar 3.000 kakab. Untuk hateup, biasanya ia bisa membeli sekitar 500 jalon daun tepus atau daun eurih. Harga satu jalon daun eurih atau tepus Rp. 1.000,00. dan harga satu kakab ijuk Rp. 3.000,00. Untuk keperluan membangun rumah, biasanya kayu yang dipergunakan adalah kayu albasiah, suren, jengjen dan rasamala dan dipilih kayu-kayu bagus dan lurus, tidak boleh kayu yang telah rubuh dan bergetah merah, karena semua itu adalah pantangan.
Kayu-kayu ini ada yang langsung dibeli dari toko material yang ada di daerah Tasikmalaya, Garut atau memotong sendiri dari kebun, kemudian kayu digangseng atau dikeringkan dengan cara di sandarkan atau diberdirikan pada dinding batu pada halaman yang luas.

Bila kayu dirasa sudah kering, kemudian disimpan di kolong rumah. Bahan material yang telah dikumpulkan biasanya disimpan di tempat yang telah disediakan, seperti kolong rumah atau sosompang yang ada di samping rumah, bahkan ada pula bahan material ini disimpan diteritis rumah lama yang akan dibongkar.

Keperluan lainnya seperti bilik, juga bisa membeli dari luar dengan harga yang variasi sesuai harga pada waktu pembelian. Adapun bilik sasak biasanya mereka membuat sendiri dari awi seurat yang ada di sekitar kebun. Bahan-bahan lainnya seperti kaca, paku, kapur, plat besi, dan portas (untuk melabur bagian-bagian tertentu dari kayu agar tidak terserang toko (binatang 'bubuk') dibeli dari toko.

Setelah lulugu merasa sudah siap untuk membangun rumahnya, ia kemudian datang kepada kuncen untuk mengajukan permintaan mempergunakan tanah adat di dalam Kampung Naga atau tanah yang berada di dalam Kandang Jaga (perkampungan yang dikelilingi oleh pagar). Tanah tersebut dapat pula merupakan tanah dari rumah lama yang dibongkar dan dibangun kembali atau membuat sendiri lelemah baru dengan cara ngurug balong (mengurug kolam) atau nugar bukit (memapas bukit). Setelah Kuncen mengizinkan, maka pembangunan pun segera akan dimulai.

Untuk memulai pembangunan sebuah rumah, lulugu datang kepada tukang atau di Kampung Naga dikenal dengan sebutan dulah. Kedatangan lulugu kepada dulah ini disebut dengan istilah ngamprah (meminta bantuan) yaitu untuk membicarakan tata cara pembangunan rumah yang sesuai dengan permintaan lulugu. Biasanya dalam pembicaraan itu 
dibicarakan segala sesuatu yang menyangkut dengan pembangunan, mulai dari gaya rumah, luas rumah, bahan-bahan apa saja yang dibutuhkan, dan yang terpenting adalah kapan waktunya dan berapa lama pembangunan akan dilaksanakan, juga yang tak kalah pentingnya adalah kapan pembangunan akan dimulai. Dalam pembicaraan itu pun dulah akan menanyakan kepada lulugu apakah rumah itu dibangun dengan cara diborongkan, diupah secara harian, atau bahkan dibangun dengan cara gotong royong? Hal tersebut berkaitan dengan gandek yang diperlukan oleh seorang dulah. Gandek adalah pembantu dulah kepala yang akan membangun rumah tersebut. Biasanya seorang dulah kepala membawa sekitar tiga sampai empat orang gandek-nya dalam membangun sebuah rumah.

Pembangunan rumah pada awalawal dilaksanakan secara gotongroyong oleh penduduk Kampung Naga yang kebetulan tidak ada kerjaan di sawah atau di ladang. Bagi mereka yang berhalangan hadir, biasanya datang meminta izin tidak bisa ikut. Warga yang ikut bergotong royong, hanya mengerjakan pekerjaan seperti, ngalelemah, membongkar rumah dan ngadegkeun. Sementara pekerjaan yang utama, yaitu membuat tiang, membuat ukuran tiang, menyerut kayu biasanya dilakukan oleh gandek dan dipimpin oleh dulah.

\section{b. Membongkar Rumah}

Sebelum pembangunan rumah baru dimulai, pembongkaran rumah lama tentu harus dilakukan. Biasanya pembongkaran rumah lama dilaksanakan apabila sudah dirasakan perlu untuk dibongkar, artinya, si pemilik rumah lama sudah siap untuk membongkar dan sudah dalam tahap persiapan mencicil mengumpulkan bahanbahan material.

Ketika rumah akan dibongkar, di sini si pemilik rumah biasanya memberitahu kepada kuncen dan dulah untuk membicarakan kapan waktu yang tepat sesuai dengan kepercayaan dan adat istiadat. Pembongkaran dilaksanakan secara bergotong royong oleh semua penduduk yang ada di Kampung Naga. Upacara kecil dilaksanakan oleh pemilik rumah dengan dipimpin dulah dan beberapa orang penduduk yang kebetulan tidak ada kegiatan di luar.

Dalam proses pembongkaran rumah lama, biasanya si pemilik rumah memilahmilah bahan material yang masih dapat dipergunakan untuk membangun rumah kembali nantinya, sedangkan material yang sudah tidak diperlukan lagi biasanya dipergunakan untuk bahan kayu bakar atau dibuang. Setelah rumah selesai dibongkar, kemudian tanah bekas rumah tersebut dibersihkan dan dilelemah.

\section{c. Ngalelemah (membuat rata tanah)}

Ngalelemah adalah proses awal dari pembangunan sebuah rumah, artinya meratakan tanah yang akan dijadikan lahan pembangun rumah baru. Kebiasaan yang dilakukan di Kampung Naga, dalam proses ngalelemah diawali dengan membongkar rumah yang lama, kemudian ngalelemah dilakukan di atas tanah yang rumahnya dibongkar. Hal itu disebabkan sempitnya lahan untuk menambah lahan baru yang ada di dalam kandang Jaga atau di lingkungan Kampung Naga.

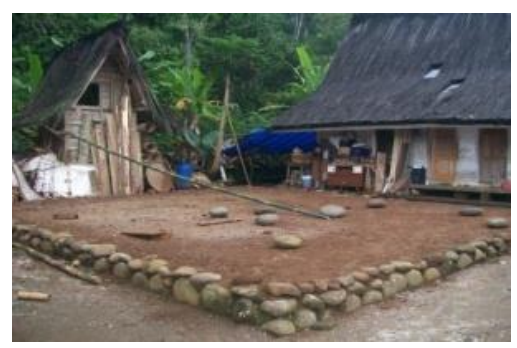

Gambar 2. Tanah bekas rumah lama dibersihkan lemudian dilelemah untuk membangun rumah baru. Sumber : Ndroes 2011

Proses ngalelemah ini biasanya dilakukan dengan cara menaikkan tinggi tanah dari tanah yang ada setinggi kurang lebih dua puluh sentimeter, kemudian disengked dengan deretan batu. Penentuan 
dan peletakan tatapakan atau disebut ngadeg kai bisanya dilakukan oleh dulah setelah ukuran rumah dan jumlah tiangtiang soko yang akan dijadikan tiang-tiang pokok atau penyangga ditetapkan, sehingga tiang-tiang itu kokoh berdiri tanpa menyentuh tanah.

Dalam proses ngalelemah ini, bagi masyarakat Kampung Naga sangat mempercayai bahwa ukuran denah rumah perlu dilebihkan dari ukuran yang telah ditentukan seluas telapak tangan pemilik atau lulugu agar kelak bila rumah itu dihuni akan memudahkan dan dikaruniai rezeki. Hal ini lebih dikenal dengan istilah panghurip. Tangan merupakan simbol dari sebuah usaha agar mencapai hurip (penuh rezeki).

\section{d. Ngadegkeun (mendirikan rumah)}

Ngadegkeun adalah tahapan dimana proses ngarakit kayu, disebut juga dengan masangkeun kayu dengan kayu atau orang Kampung Naga menyebutnya dengan ngadu-ngadu, yaitu memasangkan kayukayu untuk dijadikan tihang (tiang) atau rangka rumah yang lainnya.

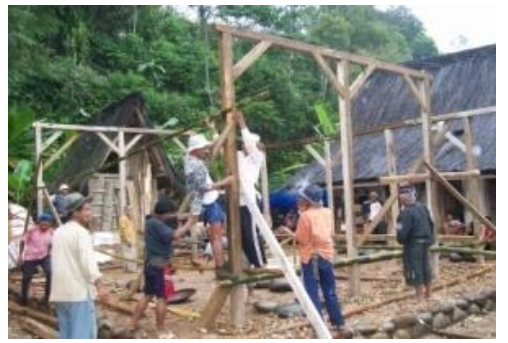

Gambar 3. Para pekerja dibawah pengawasan dulah sedang mendirikan bangunan. Sumber : Ndroes 2011

Semua pekerjaan membuat kerangka kayu dan masangkeun kayu untuk menjadi sebuah kerangka rumah itu, biasanya dilaksanakan di atas tanah yang telah dilelemah di atas tanah kosong yang berdekatan dengan tanah yang sudah dilelemah, biasanya di pinggir-pinggir rumah di sekitarnya. Hal tersebut dilakukan untuk mempermudah pemasangan dan ngadegkeun kayu-kayu yang telah dirakit tersebut.

\section{Teknik dan Cara Pembuatan}

Pekerjaan pembangunan rumah diawali dengan meratakan tanah atau disebut dengan istilah ngalelemah yang dilakukan oleh beberapa orang. Setelah proses ngalelemah selesai dilanjutkan dengan penetapan batu tatapakan yang dilakukan oleh dulah kepala. Biasanya penetapan jarak tatapakan ini disesuaikan dengan lebar dan luasnya rumah yang akan dibangun. Kemudian dilanjutkan dengan ngadegkeun yaitu mendirikan rumah. Biasanya dalam proses ngadegkeun, dikepalai oleh dulah kepala dan beberapa gandek yang bekerja untuk membantu membuat kerangka rumah, mulai dari pembuatan tiang, hingga memasangkan ijuk di atas atap.

Proses ngadegkeun merupakan proses memasangkan berbagai tiang dari balok kayu menjadi sebuah kerangka rumah. Untuk sebuah rumah yang bergaya soko akan berbeda dengan rumah yang bergaya gagalur. Rumah bergaya soko, adalah rumah yang memiliki sejumlah tiang yang langsung bertumpu pada tatapakan batu lempar. Adapun rumah bergaya gagalur, pembuatan tiang dimulai dari tiang gagajah dan tiang lulugu yang dihubungkan dengan gagalur, sehingga tatapakan yang dipergunakannya pun adalah tatapakan batu papras. Cara pembuatannya pun berbeda, hal itu dikemukakan oleh dulah kepala, bahwa rumah dengan gaya soko merupakan rumah tua dan agak rumit dalam menentukan tiang-tiangnya, sedangkan rumah bergaya gagalur lebih mudah pembuatannya.

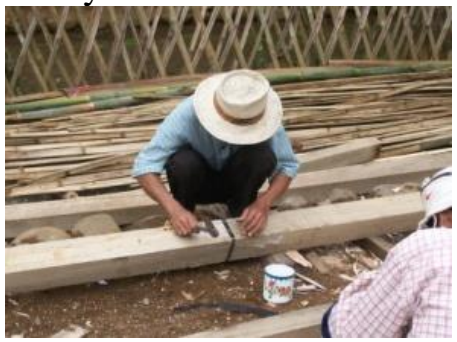

Gambar 4. Seorang pekerja sedang menyambung kayu. Sumber : Ndroes 2011 
Cara pembuatan rumah bergaya gagalur, dimulai dengan memasangkan atau merakit kayu-kayu untuk dijadikan kerangka rumah, jumlah kerangka akan ditentukan dengan katimang (deretan tiang). Pemasangan atau perakitan kayu biasanya dilakukan di tempat lelemah yang telah dibuat. Kepala dulah dan gandek atau warga masyarakat yang lainnya membantu memadukan tiang, dimulai dari tiang lulugu dan tiang gagajah. Semua tiang diperkuat atau disatukan dengan kayu yang dipasang horizontal setinggi dada orang tua, tiang ini disebut palang dada. Di bawah tiang gagajah dan lulugu disatukan dengan kayu yang horizontal disebut gagalur. Sementara di bagian atas dipasang balok kayu sejajar palang dada dan gagalur yang disebut pangeret, di atasnya dipasang tiang adeg untuk menunjang suhunan, kemudian diperkuat dengan kayu siku-siku yang dipasang miring. Teknik menghubungkan antara kayu dengan kayu disambung dengan cara dipaku dan diperkuat dengan plat besi. Ada dua cara teknik penyambungan, yaitu penyambungan kayu dengan cara cakop dan dihuntu-huntu.

Dulah kepala adalah orang yang dipercayai untuk memimpin pembangunan sebuah rumah, maka pelaksanaan membuat kerangka rumah selalu dibawah pengawasannya. Dulah kepala akan selalu melihat bahwa kerangka rumah yang masih berupa tiang-tiang ini dibangun mulai dari arah timur, tiang-tiang ini disebut sebagai tiang-tiang pangpayunna (tiang yang pertama).

Untuk menentukan arah rumah harus saling berhadapan, maka penempatan ruang-ruang di dalam rumah pun harus sesuai dengan weton (hari lahir) istri dan suami yang mempunyai rumah. Hal tersebut berpengaruh pula terhadap kayu-kayu yang akan dipasangkan, misalnya puhu kayu (pangkal kayu) harus disimpan arah timur dan congo kayu (ujung kayu) harus disimpan arah barat. Barat dan timur menunjukkan simbol awal dan akhir dari kehidupan. Suami adalah guru jadi harus di timur (melihat keluarnya matahari) atau dalam bahasa Sunda disebut 'meletek panon poe'. Dan Istri menunjukkan arah barat, karena arah barat adalah akhir surupna panon poe (melihat tenggelamnya matahari). Begitu pula pembuatan tiang kayu, bahwa puhu harus disimpan di bawah dan congo harus di atas, hal ini menunjukkan simbolisasi antara ibu atau orang tua dan anak, ibu atau orang tua berada di bawah dan anak selalu berada di atas.

\section{Tenaga Pelaksana}

Untuk pengerjaan sebuah rumah, di Kampung Naga diperlukan tenaga kerja beberapa orang. Istilah yang diberikan kepada pekerja yang membuat rumah di Kampung Naga disebut sebagai dulah, yaitu seorang tukang yang mengerjakan berbagai hal yang berhubungan dengan pembuatan rumah. Biasanya dulah ada yang disebut dulah kepala, yaitu orang yang dipercayai menjadi kepala yang mengawasi pembangunan rumah secara keseluruhan. Tugas dulah kepala mulai dari merancang bangunan, menentukan berapa orang pembantu (gandek) hingga mengawasi semua pekerjaan gandek. Pekerja lain yang dibawa oleh seorang dulah kepala adalah gandek, yaitu orang yang membantu dulah kepala dalam membuat rancangan kerangka rumah hingga selesai menjadi rumah. Banyaknya gandek yang diperlukan dalam membuat satu rumah, biasanya ditentukan oleh dulah kepala. Keahlian gandek biasanya tersebar dalam beberapa keahlian, misalnya menyerut kayu, menyambung kayu dan menghitung berapa jumlah kayu yang akan diperlukan untuk membangun rumah. Begitu pula membantu dulah kepala dalam menentukan posisi tiang atau menghitung jumlah tiang, jumlah hateup yang diperlukan dan jumlah kakab ijuk yang diperlukan untuk sebuah atap rumah dengan ukuran yang berbeda. 


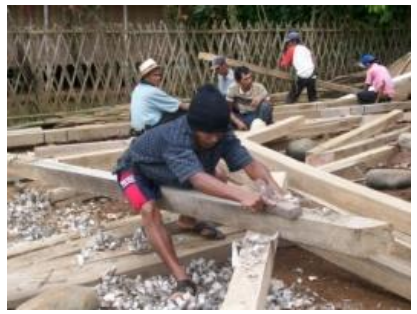

Gambar 5. Pekerja menyerut (nyugu) kayu untuk dijadikan tiang.

Sumber : Ndroes 2011

Pembangunan sebuah rumah baik dikerjakan langsung tanpa diborongkan maupun diborongkan, dulah kepala dan gandek biasanya sudah ditentukan dalam artian bahwa dulah kepala dan gandek harus ada. Pembangunan yang diborongkan adalah pekerjaan yang seluruhnya diserahkan kepada dulah kepala dan gandek dari awal hingga akhir, masyarakat umum biasanya membantu pada hal-hal kecil seperti ikut dalam ngalelemah, ngadegkeun tiang rumah, dan memasangkan atap. Namun bila pembangunan rumah itu tidak diborongkan, bisanya masyarakat umum ikut membantu dalam pembangunan tersebut. Dulah kepala dan gandek hanya membuat dan mengerjakan pekerjaan yang utama saja, misalnya membuat kerangka rumah, membuat sambungan kayu, dan finishing-nya.

\section{Beberapa Upacara}

Ada beberapa tahap upacara selamatan yang dilakukan oleh warga Kampung Naga dalam membangun rumah. Tahapan ini berlaku bagi seluruh warga, namun berbeda bagi setiap orang dalam menentukan waktu membangun rumah. Istilah yang dipergunakan dalam upacara selamatan disebut dengan ngarajah.

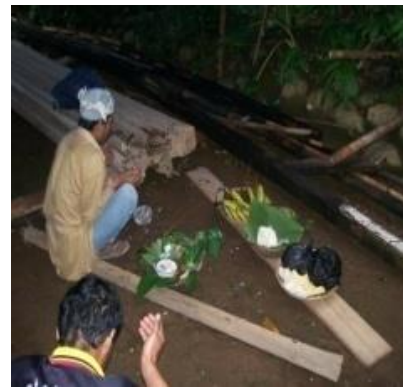

Gambar 6. Tukang ngarajah sedang berdoa, sebelum memasangkan kayu. Sumber : Ndroes 2011.

Ngarajah ini dapat berarti menghitung waktu yang tepat dan dapat pula berarti meminta restu dari para karuhun. Proses pertama yang dilakukan oleh si pemilik rumah adalah ngarajah. Ngarajah berarti menghitung waktu yang tepat bagi seseorang dalam membangun rumah, yang dilakukan oleh tukang rajah sebelum membangun rumah. Pembangunan rumah tidak boleh pada bulan Maulud dan Sapar, hal tersebut disebabkan pada bulan Maulud, warga secara adat mengganti pagar kandang jaga, dan bulan Sapar merupakan bulan kawin anjing, yang akan membawa kesialan bagi orang yang melakukan pekerjaan. Kedua, menentukan lokasi, rumah tidak boleh ngalangkangan (membayangi) rumah orang tua atau kakak yang lebih tua. Hal tersebut akan menimbulkan bencana bagi si pemilik rumah. Ketiga, adalah menentukan arah pintu masuk, pintu masuk harus berhadap-hadapan dengan rumah yang ada di depannya. Keempat, adalah menentukan ukuran rumah, yaitu dengan cara menghitung panjang deupa (depa) si suami pemilik rumah dikurangi panjang telapak dan jari tangan kanan. Cara menghitungnya telapak diberi angka 1, kelima jari diberi angka 2, 3, 4, 5, 6 . Kembali ke pusat, telapak diberi angka 7 , kelima jari mempunyai angka 8, 9, 10,11, 12. Perputaran dilanjutkan hingga angka di telapak mencapai 25. Jadi luas terkecil rumah yang ada di Kampung Naga adalah $25 \mathrm{~m}^{2}$. Luas rumah yang lain adalah 31,37 , $43,49,55,61,67,73 \mathrm{~m}^{2}$. Ukuran rumah tidak boleh genap, harus merupakan bilangan pecah, misalnya rumah berukuran $25 \mathrm{~m}^{2}$ sisinya tidak boleh $5 \times 5 \mathrm{~m}^{2}$, melainkan harus $4 \times 6,25 \mathrm{~m}^{2}$. Angka 0,25 merupakan angka panghurip (agar rejeki selalu ada). Bila hal itu tidak dilakukan, maka tidak ada panghurip, maka rezeki akan bungblas (tidak ada rezeki yang datang). Kelima, adalah ngawitan motong (memulai menebang pohon). Untuk 
memulai persiapan pembangunan sebuah rumah, biasanya warga akan menebang pohon untuk bahan tiang.

\section{a. Sebelum Mendirikan Rumah}

Tukang ngarajah yang bertanggungjawab dalam melaksanakan ngarajah (meminta doa restu) kepada Tuhan dan Karuhun, dimulai dari proses pelaksanaan nuar (menebang) kayu di kebun. Salametan dilakukan di rumah pemilik rumah dihadiri oleh kerabat dekat. Setelah doa diucapkan, dilanjutkan makan bersama. Semua perlengkapan upacara dibawa tukang ngarajah ke kebun atau hutan tempat penebangan akan dilakukan (Adimihardja, dkk, 1986 : 72). Tukang ngarajah, tukang menebang kayu, dulah, beberapa gandek dan pemilik rumah berangkat ke kebun untuk memilih pohon manglid yang baik untuk dijadikan tiang. Sebelum penebangan dimulai, tukang ngarajah memulai doa sambil membakar kemenyan. Setelah pohon kayu roboh, maka ia duduk bersila di puhu 'pangkal' kayu untuk berdoa kembali. Kayu yang telah roboh kemudian dijadikan balokbalok untuk tiang-tiang. Kegiatan membuat balok-balok kayu disebut natahan.

Sesajen yang dibawa oleh tukang ngarajah adalah (1) Cai beas 'air cucian beras' dicampur dengan daun jawer kotok, (2) Kemenyan, (3) Lemareun, terdiri atas sirih, kapur, dan pinang.

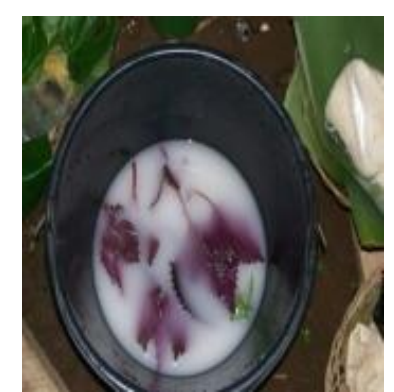

Gambar 7. Cai beas dan daun jawer kotok untuk dicipratkan pada semua peralatan tukang. Sumber : Ndroes 2011

Cai beas yang dicampur dengan daun jawer kotok berfungsi sebagai air untuk membilas peralatan seperti bedog (golok), gergaji, dalam proses mengasah agar lebih tajam. Selain itu, cai beas ini pun diciprat-cipratkan pada pohon yang akan dijadikan balok-balok kayu. Kayukayu yang sudah dijadikan balok dibawa ke kampung untuk dikeringkan dengan cara disandarkan pada dinding sengked batu atau digangseng.

Tugas tukang ngarajah belum selesai sampai di sana, karena ketika akan dimulai pembangunan rumah pun, tukang ngarajah adalah orang yang bertanggungjawab dalam kelancaran pekerjaan. Untuk memulai pembangunan rumah, pada hari yang telah ditentukan sesuai dengan weton pemilik rumah, biasanya weton suami istri dihitung, disatukan menjadi hari $\mathrm{H}$. Pada pagi hari sekali, tukang ngarajah diikuti oleh dulah, pemilik rumah, gandek, dan beberapa orang yang akan mengikuti pembangunan rumah berkumpul di pelataran rumah melakukan rajahnya.

Sesajen yang disediakan oleh si pemilik rumah adalah : pangradinan, daun sirih, kapur sirih, gambir, jebug (buah jambe), tembakau, minyak klendah (yang dipergunakan untuk melicinkan sugu 'nama peralatan tukang untuk meratakan permukaan kayu'), bawang putih, bawang merah, beras, uang, sisir, cermin, panglay, cai beas, daun jawer kotok, tektek (sirih yang siap dimakan), hahampangan (makanan ringan beberapa kue, seperti wajit, opak, raginang, kue-kue), congcot(nasi congcot), pisang, dupi, kupat, dan kemenyan.

Ngarajah dimulai pada pagi hari, setelah itu cai beas, seperti pada awal menebang, sama berfungsi untuk membilas peralatan dan diciprat-cipratkan pada semua balok yang akan dijadikan tiang. Setelah proses ngarajah selesai barulah pekerjaan dimulai dengan cara mencipratkan cai beas ke segala arah dan pada balok-balok kayu serta semua peralatan. Dulah, gandek dan semua orang yang menghadiri proses ngarajah, memulai pekerjaannya masing-masing. 


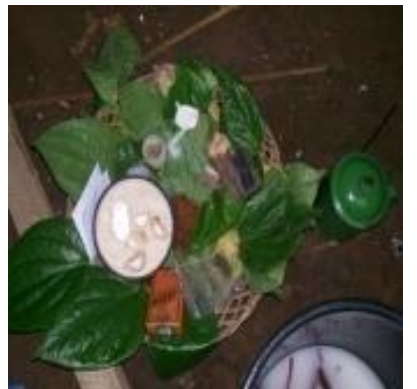

Gambar 8. Daun sirih, beras, bawang putih, sisir, rokok, dan minyak klendah menjadi sesajen utama. Sumber : Ndroes 2011.

\section{b. Sedang Mendirikan Rumah}

Proses ngarajah pada waktu membangun rumah dilakukan pada saat kerangka rumah telah selesai didirikan dan akan membangun kerangka atap yang disebut dengan ngadegkeun. Tukang ngarajah di sini berperan kembali, biasanya pemilik rumah menyediakan tumpeng dan menyembelih ayam, sedangkan sesajen yang disediakan adalah : cai beas dan daun jawer kotok, kemenyan, lemareun, daun congkok, sulangkar, padi, baju suami istri.

Pelaksanaan ngarajah dilakukan di tengah-tengah rumah yang sedang dibangun, di tengahnya dibuat sebuah lubang untuk mengubur sirih pinang (lemareun), sulangkar, dan daun congkok, dan kepala ayam. Tukangrajah berdoa di depan lubang dekat tiang pertama yang dibangun. Biasanya ngarajah dihadiri oleh kerabat dan semua pekerja.

Kerangka rumah dilihat dari titiktitik tiang yang dijadikan tempat untuk melakukan proses ngarajah pada waktu mendirikan rumah. Bulat di tengah tempat di mana sesajen disiapkan dan kotak menunjukkan lubang untuk mengubur kepala ayam dan sejumlah sesajen lainnya.

Semua tiang yang telah berdiri diciprati dengan cai beas dan daun jawer kotok, penyembelihan ayam dilakukan di tengah lubang dan kemudian kepalanya dikuburkan di tengah-tengahnya. Sementara darahnya dioles-oleskan pada semua tiang rumah, dan baju suami istri pemilik rumah diselipkan pada tiang pokok.

\section{c. Setelah Mendirikan Rumah}

Proses selamatan setelah rumah selesai disebut dengan salametan ngalih bumi yaitu selamatan setelah selesai semua pekerjaan membangun rumah. Semua kerabat, tetangga, dulah, gandek dan pekerja berkumpul di tengah rumah yang sudah selesai dengan disediakan tumpeng dan lauk-pauknya oleh si pemilik rumah. Tukang ngarajah berdoa di depan sesajen sambil membakar kemenyan, kemudian tumpeng dimakan bersama-sama dalam suasana yang gembira.

Salametan ngalih bumi (upacara selamatan mengisi rumah) yang dilakukan ini dihadiri oleh sesepuh kampung atau kuncen, bisanya dilaksanakan sesuai weton suami istri yang dihitung disatukan. Biasanya dilaksanakan pula ritual memasukkan barang dari pintu yang telah ditentukan sesuai dengan perhitungan. Sementara itu cai beas dan daun jawer kotok diciprat-cipratkan ke segala arah di dalam rumah. Biasanya barang pertama yang masuk ke dalam rumah adalah padaringan (tempat menyimpan beras), bantal, dan damar (lampu tempel).

\section{PENUTUP}

Masyarakat Kampung Naga, menyadari betul bahwa eksistensi adat istiadatnya sangat bergantung pada dirinya sendiri (masyarakat keseluruhan) sebagai warga yang mengusung kebudayaannya sendiri. Adat istiadat adalah modal dasar untuk kelangsungan hidupnya. Melestarikan adat dan budayanya berarti menjaga kelangsungan berkehidupan bagi generasi penerusnya.

Proses mendirikan sebuah rumah tak lepas dari proses ritual yang secara adat selalu dipatuhi dan dilaksanakan dengan benar, hal tersebut sangat erat kaitannya dengan sistem kepercayaan yang mereka anut. Kenapa hal itu dilaksanakan, karena mereka takut akan melanggar pamali Demikian pula rumah dan pola perkampungan yang ada di Kampung Naga erat hubungannya dengan alam sekitar, sehingga rumah dapat dianalogikan 
sebagai (mikro kosmos) atau bumi (makro kosmos) yang berarti alam semesta.

Rumah bagi masyarakat Kampung Naga dalam kesehariannya dapat berfungsi sebagai tempat menyimpan bahan makanan yaitu dengan adanya goah dan leuit di dalam rumah. Sementara itu, fungsinya yang lain sebagai tempat untuk menerima tamu, selain golodog kini ada ruang tepas yang menjadi ruang tambahan Selain itu rumah berfungsi sebagai tempat istirahat, tidur dan meneruskan keturunan dengan adanya ruang pangkeng atau geusan. Dalam lingkup yang lebih jauh, imah dapat berfungsi sebagai tempat upacara atau selamatan daur hidup mulai dari kehamilan, kelahiran, perkawinan sampai kematian.

\section{DAFTAR SUMBER}

Antar, Yori. 2010.

(ed) Pesan dari Wae Rebo: Kelahiran Kembali Arsitektur Nusantara Sebuah Pelajaran dari Masa Lalununtuk Masa Depan. Jakarta. Gramedia.

Balandier, Geoerges. 1986. Antropologi Politik terjemahan Y. Budisantoso, Jakarta, CV. Rajawali.

Basrowi. 2005.

Pengantar Sosiologi. Bogor: Ghalia Indonesia.

Geertz, Clifford. 1981.

Abangan, Santri, Priyayi dalam Masyarakat Jawa. Jakarta: PT. Dunia Pustaka Jaya. 1992.

The Interpretation of Cultures: Selected Essays. Dialihbahasakan oleh Francisco Budi Hardiman dengan judul Tafsir Kebudayan. Yogyakarta: Kanisius.

Ihromi, T.O. 2000.

Pokok-Pokok Antropologi Budaya. Jakarta: Yayasan Obor Indonesia.

Keesing, Roger, M. 1992.

Antropologi Budaya Suatu Perspektif Kontemporer Edisi Kedua. Alih Bahasa R.G. Soekadjo, Jakarta: Penerbit Erlangga.

Koentjaraningrat. 1981.
Beberapa Pokok Antropologi Sosial. Jakarta: PT. Dian Rakyat. 1987.

Sejarah Teori AntropologiI. Jakarta: Universitas Indonesia.

Liliweri, Alo. 2003.

Makna Budaya dalam Komunikasi Antarbudaya. Yogyakarta: LkiS.

Maria, Siti, dkk.1995.

Peranan Tabu dalam Pelestarian Lingkungan pada Masyarakat Kampung Naga. Jakarta. Proyek IDKD. Departemen Pendidikan dan Kebudayaan.

Mulyana, Deddy. 2000.

Ilmu Komunikasi: Suatu Pengantar. Bandung: Remaja Rosdakarya.

Poerwanto, Hari. 2000.

Kebudayaan dan Lingkungan: Dalam Perspektif Antropologi. Yogyakarta: Pustaka Pelajar.

Ritzer, George dan Goodman, J. Douglas. 2004. Teori Sosiologi Modern. Jakarta: Prenada Media.

Suganda. Her. 2006. Kampung Naga Mempertahankan Tradisi.Bandung. Kiblat.

Tjahjono, Gunawan. 2010. Membangun Diri dan Mendiri Bangun dalam Pembuatan RumahAdat di Desa Wae Rebo : Suatu Pengantar. Dalam Pesan Dari Wae Rebo. Jakarta. Gramedia.

Turner, H., Jonathan.1967.

The Structure of Sociological Theory. Homewood: The Dorsey Press. 